\title{
DEVELOPMENT OF COMMUNICATION POSSIBILITIES BETWEEN PARTICIPANTS OF THE TEMPORARY CHILD GUARDIANSHIP SITUATION: THE RELATION OF VARIABLES
}

\author{
Daiva Alifanoviene \\ Siauliai University, Lithuania \\ Asta Vaitkeviciene \\ Siauliai University, Lithuania \\ Dovile Kauneckiene \\ Siauliai University, Lithuania \\ Rita Orska \\ Rezekne Academy of Technologies, Latvia
}

\begin{abstract}
Based on the quantitative research results, the article deals with communication peculiarities of the participants of the temporary child guardianship situation - children and their biological parents whose parental rights are temporarily limited - at the temporary foster care institution in the aspect of specialists working there. Using descriptive mathematical statistics and statistical analysis methods, specialists' opinion about the causes of disagreements between specialists and learners, the causes of disagreements between parents and specialists, and communication development possibilities of the participants of the temporary child guardianship situation were analysed.
\end{abstract}

Keywords: children's temporary guardianship, biological parents, learners of temporary childcare institutions, social educators / social workers.

\section{Introduction}

The United Nations Convention on the Rights of the Child (1989), which Lithuania has ratified, notes that all children must be provided with appropriate conditions for their full-fledged development, protection and assurance of rights. It often happens that children's rights and development prospects to suitably grow and develop in biological parents' homes are violated. In such cases, parents lose the possibility to grow and take care of their children themselves, there appears a necessity for professionals, who can ensure children's safety and appropriate education, to intervene in the internal life of the family. The most common causes due to which children cannot grow in parental families are parents' neglect of their child, their unconcern, inappropriate upbringing, physical or psychological violence. If the child's rights and possibilities to grow 
Daiva Alifanoviene, Asta Vaitkeviciene, Dovile Kauneckiene, Rita Orska. Development of Communication Possibilities Between Participants of the Temporary Child Guardianship...

and develop in the biological family are limited, according to the Civil Code of the Republic of Lithuania, the child under the age of 14 is awarded guardianship, the child older than 14, curatorship.

Data provided by The Lithuanian Department of Statistics demonstrate that between 2010 and 2014, the number of children growing in childcare homes was gradually decreasing. The number of children who were deprived of parental care per year is also decreasing; however, comparing the data of 2010 with the data of 2014, the number of children taken into temporary guardianship increased; the number of children who returned to their parents from temporary guardianship also remains little decreased (see Table 1).

Table 1 Child Guardianship Tendencies in Lithuania

\begin{tabular}{|l|c|c|c|c|c|}
\hline \multicolumn{1}{|c|}{ Years } & 2010 & 2011 & 2012 & 2013 & 2014 \\
\hline $\begin{array}{l}\text { The number of children in foster care in } \\
\text { families, N }\end{array}$ & 6651 & 6289 & 6105 & 5906 & 5681 \\
\hline $\begin{array}{l}\text { The number of children growing in child } \\
\text { care homes, N }\end{array}$ & 5000 & 4870 & 4611 & 4368 & 4086 \\
\hline $\begin{array}{l}\text { Children deprived of parental care per } \\
\text { year, N }\end{array}$ & 2145 & 2305 & 2055 & 2112 & 1871 \\
\hline $\begin{array}{l}\text { The number of children who returned to } \\
\text { their parents, N }\end{array}$ & 768 & 811 & 801 & 927 & 754 \\
\hline $\begin{array}{l}\text { The number of children who were taken } \\
\text { into temporary guardianship, N }\end{array}$ & 127 & 112 & 103 & 137 & 154 \\
\hline
\end{tabular}

Source: The Lithuanian Department of Statistics http://osp.stat.gov.lt

The Child Welfare State Policy Concept stipulates that support provision for the child in the first place must be based on the network of the environment closest to the child, since the loss / death of both parents is attributed to catastrophic stressors (Pileckaite-Markovienè, Lazdauskas, 2007). Therefore, designating guardianship to the child, the following priorities are followed: 1) the child's return to the biological family, 2) the child's adoption, 3) the child's long-term guardianship (The Child Welfare State Policy Concept, 2003).

In order to protect the child from danger and at the same time not to violate his / her right to grow in the family, The Child Welfare State Policy Concept (2003), The Child Wellbeing Programme (2013-2018) provide for the most important trends of creating well-being for children and their families. The key provision of these documents is to ensure the child's life and self-education possibilities in the family; in case of complicated family situations, to create conditions for children's return to their biological families; organize the support network for families at-risk; promote parents not to terminate relationships with 
children; and solve arising difficulties due to which children were taken away from the family.

The modern concept of child guardianship unconditionally emphasizes the priority of non-institutional child guardianship because children who have lost parental care undergo a double trauma: they experience and perceive parents' bad behaviour with them and suffer from forced separation from the family, which almost equals to parental death. Therefore, specialists ensuring child guardianship forms should aim to minimize and mitigate such a painful loss as much as possible. This aim can be achieved by projecting conditions for returning of children to their biological families, organized network of assistance for families at-risk, parents' promotion not to terminate relationships with children and solve arising difficulties due to which children were taken away from the family (Alifanovienè, Vaitkevičienè, Kauneckienè, 2015).

Vitkauskas (2010) states that the child's temporary guardianship should not continue without restriction because in such case the child's right to be cared for in the family and to grow in the closest people's environment is violated. Therefore, it is important that specialists organising temporary guardianship of children should develop communication between children in the temporary guardianship situation and their biological parents, seek that parents, whose rights to foster and take care of their children are temporarily limited, change their lifestyle and children can return to the family of their biological parents.

Although Radzevičienè (1999) emphasized that one of the key tasks of the social educator or social worker working in the care institution was to help parents to overcome the crisis situation due to which the child was taken to the care institution. However, the research conducted by Sivec (2005) indirectly discloses that the weakest field of social educators' activity remains the same work with learners' parents.

Data of the research conducted by Rimkevičienè (2007) also demonstrate that social educators working in child care homes pay too little attention to work with biological families of children in care although they know and agree that this area of work is important. Too little attention of specialists for parents of children in temporary guardianship may be one of the reasons why so few children are returned to their biological families and why such large number of children are designated permanent guardianship or curatorship in institutions or families, large families.

Thus, the problem field of this article is defined by questions: What are the peculiarities of communication between the participants of the temporary child guardianship situation? What conflicts arise between social educators, social workers and the participants of the temporary child care situation? What are the possibilities of developing communication between children who have the status of temporary guardianship and their biological parents? 
Daiva Alifanoviene, Asta Vaitkeviciene, Dovile Kauneckiene, Rita Orska. Development of Communication Possibilities Between Participants of the Temporary Child Guardianship...

The research object: peculiarities of communication between social educators / social workers working in child care institutions and the participants of the guardianship situation (parents and their biological parents).

The research aim: to analyze peculiarities of communication between social educators / social workers working in child care institutions and the participants of the guardianship situation (parents and their biological parents).

\section{Research objectives:}

1. To identify causes of conflicts between children who temporarily live in care institutions, their biological parents and specialists.

2. To disclose social educators'/ social workers' opinion about the possibilities of developing communication between children who temporarily live in care institutions and their biological parents.

The research sample. The search for research participants took place using the website of The Ministry of Social Security and Labour ${ }^{1}$ of the Republic of Lithuania. From the list of child care institutions given on the website the specific institutions in which children are cared for only on a temporary basis and work with the children's biological families is carried out were selected. Such institutions where children living in them have the possibility to return to biological parent families (there are 14 such institutions in Lithuanian cities and districts, and they employ 98 social educators / social workers) were selected using purposive sampling. Each head of the institution or senior social educator / social worker were contacted personally requesting them to participate in the questionnaire survey and asked to urge their colleagues to fill in the e-questionnaire ${ }^{2}$. Conducting the questionnaire survey, the following difficulties of research data collection were observed: a share of heads of temporary care institutions accepted the request to urge their staff to fill in sent electronic questionnaires unsympathetically, stating that they "had no time" for that, that they get similar questionnaires "every day and more than one of them", that other researchers who want to get answers to the questions in the questionnaire "compensate for that considerably". Thus, due to these difficulties, only 59 out of 98 social educators / social workers filled in the questionnaires.

The majority of respondents were female $(\mathrm{N}=53)$, compared with the number of male respondents $(\mathrm{N}=6)$. The data show that women prevail in care institutions. The age of the majority of respondents $\mathrm{N}=26$ is $41-45$ years, fewer respondents $(\mathrm{N}=12)$ are between 25 and 30 years old. Specialists aged between 36 and 40 and between 31 and 35 constituted the smallest share of respondents

\footnotetext{
${ }^{1} \mathrm{http}: / /$ www.socmin.lt/lt/seima-ir-vaikai/vaiko-teisiu-apsaugos-istaigos/vaiku-globos-istaigos/vaiku-globosnamai.html

${ }^{2}$ http://apklausa.lt/f/anketa-skirta-socialiniams-pedagogams-socialiniams-darbuotojams-dirbantiemsbefzy17.fullpage
} 
$(\mathrm{N}=2)$. The obtained data show that usually middle-aged staff is employed in temporary care institutions.

According to education, the largest group of respondents $(\mathrm{N}=52)$ consisted of the ones who had a university degree, the smallest group $(\mathrm{N}=7)$, higher college education. It can be reasonably stated that care institutions employ qualified social educators and social workers. Their distribution in these institutions is very similar: social educators, $\mathrm{N}=29$, social workers, $\mathrm{N}=30$.

The analysis of seniority of specialists working in care institutions shows that the largest group of respondents $(\mathrm{N}=27)$ has worked in such institutions from 5 to 10 years and up to 5 years $(\mathrm{N}=19)$. There were least respondents $(\mathrm{N}=11$ and $\mathrm{N}=2)$ who have worked in care institutions 11-15 and 16-20 years.

Research methods. The research employed the quantitative research instrument - the questionnaire consisting of 4 demographic questions, 12 factual type questions about peculiarities of meetings and communication of children and their biological parents and 12 diagnostic areas, each of which is defined by statements. In this article we will present only such diagnostic areas which enable to disclose causes of conflict situations between children, biological parents and social educators / social workers working in child care institutions and possibilities of developing parent-child communication.

Respondents were asked to evaluate statements of diagnostic areas using a five-point rating scale (1 point - "strongly disagree"; 2 points - "partially disagree"; 3 points - "a neutral position"; 4 points - "partially agree", 5 points "strongly agree"). Diagnostic areas were defined on the basis of researches (Butvilas, 2004; Kondrotaite, 2006; Samašonok, Žukauskienė, Gudonis, 2006). Statements of diagnostic areas were selected from interviews with children who were designated temporary guardianship and with their biological parents (Kauneckienè, 2014).

Reliability of statements constituting diagnostic areas was tested using Cronbach's alpha coefficient. Cronbach's alpha of the scale of causes of conflict situations between parents and children is 0.986; of causes of conflicts between children and specialists of temporary care homes, 0.963; of causes of conflicts between parents and specialists of temporary care homes, 0,977; of development of communication possibilities between children and biological parents, 0.697. High coefficients of three scales indicate that they are suitable for group researches for determining causes of conflict situations between children experiencing exclusion and parents, causes of conflicts between children experiencing exclusion and specialists providing social assistance, and causes of conflicts between parents whose parental rights are limited and specialists providing social assistance (Pakalniškienè, 2012:11).

The factor analysis method with Varimax rotation was applied for the said scales. The KMO coefficient value of the scale causes of conflict situations 
Daiva Alifanoviene, Asta Vaitkeviciene, Dovile Kauneckiene, Rita Orska. Development of Communication Possibilities Between Participants of the Temporary Child Guardianship...

between children experiencing exclusion and parents equals 0,923, Bartlett sphericity test: $\mathrm{p}=0,000$. No statement was eliminated because for all statements of the scale Anti-image Correlation MSA>0,5. Using the principal component analysis method, only one factor was obtained, therefore it did not make sense to continue the factor analysis although this only factor explains a quite high $(83,7 \%)$ dispersion of causes of conflict situations between parents and children.

The KMO coefficient value of the scale causes of conflicts between children and specialists of temporary care homes equals 0,887, Bartlett sphericity test: $\mathrm{p}=0,000$. No statement was eliminated because for all statements of the scale Anti-image Correlation MSA> 0,5. The principal component analysis method resulted in two factors, which explain $84,87 \%$ of dispersion of causes of conflicts between children and specialists of temporary care homes in the context of this research.

The KMO coefficient value of the scale causes of conflicts between parents and specialists of temporary care homes equals 0,901, Bartlett sphericity test: $\mathrm{p}=0,000$. No statement was eliminated because for all statements of the scale Anti-image Correlation MSA> 0,5. The principal component analysis method resulted in two factors, which explain $85,02 \%$ of dispersion of causes of conflicts between parents and specialists of temporary care homes in the context of this research.

The KMO coefficient value of the scale development of communication possibilities between children and biological parents equals 0,677, Bartlett sphericity test: $p=0,000$. The principal component analysis method resulted in 7 factors, which after Varimax rotation reduced to 4 . These remaining 4 factors explain $75,12 \%$ of dispersion of development of communication possibilities between children and biological parents in the context of this research.

\section{Analysis of Research Results}

Communication with biological parents and seeing them are important for every child. Social educators and social workers involved in the research disclosed that children temporarily living in care institutions were most often visited by the mother $(94,9 \%)$, grandmother or grandfather $(81,4 \%)$ and sister / brother $(52,5 \%)$. Most rarely children are visited by both parents $(6,8 \%)$ and godparents $(6,8 \%)$. These data show that persons who are the closest and most caring for the child are his / her mother, grandparents and senior brothers / sisters. Meanwhile, the father turns up at the care institution less often than the mother, grandparents and brothers / sisters. It can therefore be assumed that child-father ties are often broken still before minors are taken to the care 
institution. This can be determined by parental divorces, conflicts, disagreements between parents.

No matter how important communication with biological parents for the child is, specialists working in as many as 49 temporary care homes disclosed that they often saw conflict situations between children and the staff visiting them. They also acknowledged that there were conflicts between themselves and children who were temporarily deprived of parental care, between themselves and children's biological parents. The means of data collected during the questionnaire survey enabled to disclose causes of the most common conflicts between children and their biological parents. They are illustrated in Figure 1.

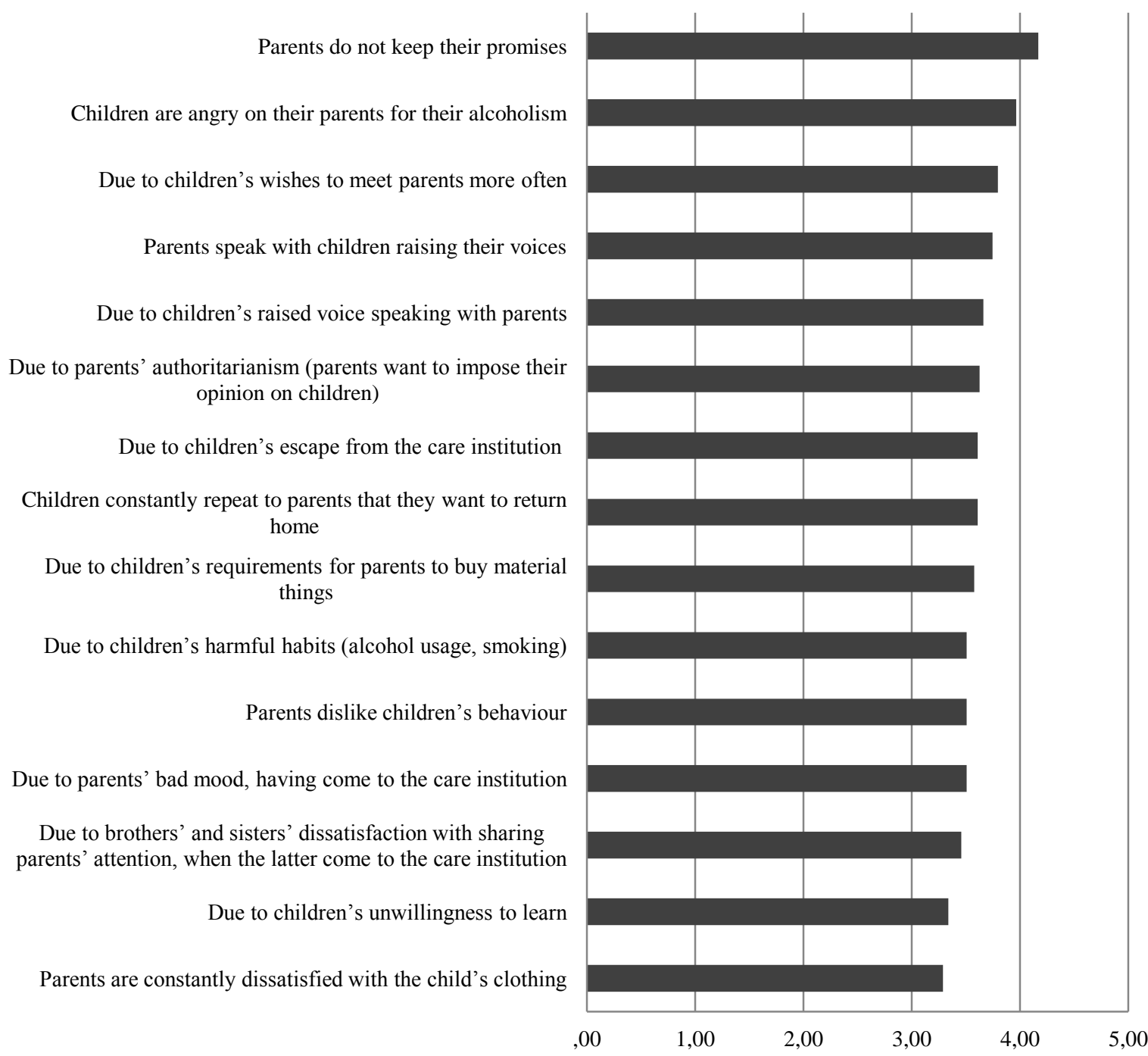

Fig. 1 Causes of Conflicts between Children Living in Temporary Child Care Homes and their Biological Parents 
Daiva Alifanoviene, Asta Vaitkeviciene, Dovile Kauneckiene, Rita Orska. Development of Communication Possibilities Between Participants of the Temporary Child Guardianship...

The data of the diagram show that the most important cause of conflicts between children who are designated temporary guardianship and biological parents from social educators' and social workers' standpoint is parents' unfulfilled promises $(\mathrm{M}=4,17 ; \mathrm{SD}=1,375)$. In specialists' opinion, children's anger towards parents is provoked by disappointment in the dearest people. Children are also angry due to parental alcoholism $(\mathrm{M}=3,97 ; \mathrm{SD}=1,389)$ and rare visits. Evaluation of causes of parent-child conflict situations identified by social educators and social workers enables to assume that non-fulfilment of parental promises is related to their rare visits to the care institution and children's wish to see parents more often $(\mathrm{M}=3,80 ; \mathrm{SD}=1,336)$. It may be that namely this is the reason of children's reproaches to parents, while parents who defend themselves from children's reproaches speak with a raised voice $(\mathrm{M}=3,75 ; \mathrm{SD}=1,372)$, which further irritates children and they also respond to parents with the same raised tone of voice $(\mathrm{M}=3,66 ; \mathrm{SD}=1,321)$. Meanwhile, parents, wishing to maintain a "sliding" authority in the children's eyes, behave in the authoritarian way $(\mathrm{M}=3,623 ; \mathrm{SD}=1,23)$. It is likely that this way the chain of conflictual parent-child communication, originating from parents' inappropriate lifestyle, is formed. Parents who have lost the right to the child care are not wise enough to discontinue the formed parent-child conflictual communication chain, while children are also not able to change anything in such situation due to their age and lack of life experience.

Children who live in the temporary child care home experience the confusion of feelings: on the one hand, like all children, they love their parents and want them to be with them as often as possible; on the other hand, living in temporary child care homes, they experience the prosocial life agenda, different routine compared to the one in the biological family and perceive that their parents' way of life differs from the socially desirable way of life. For this reason they are angry on their parents that they are forced to suffer consequences of their inappropriate lifestyle (children keep repeating to their parents that they want to get home $\mathrm{M}=3,61 ; \mathrm{SD}=1,218$ ). However, children do not want to accept the order prevailing in child care homes as well (parents conflict with children due to their escape from the care institution $M=3,61$; $\mathrm{SD}=1,232$ ) because it is alien; its acceptance would equal betrayal of parents.

Social educators, social workers working in child care homes do not notice (see estimators of statements) conflicts arousing between children deprived of parental care and their biological parents due to children's reluctance to learn $(\mathrm{M}=3,34 ; \mathrm{SD}=1,198)$ or due to parents' dissatisfaction with the child's clothing $(\mathrm{M}=3,29 ; \mathrm{SD}=1,218)$. A large standard deviation shows that social educators, social workers are more inclined not to approve rather than approve of causes of these conflict situations. It can therefore be assumed that social educators and 
social workers are more likely not to believe that parents who have lost the right of the child's care bother about their biological children or their future.

The factor analysis disclosed two groups of causes of conflicts between specialists working in temporary child care homes and learners; weight of factors of statements and mean values of estimators of statements enable to see which causes of conflicts specialists observe and acknowledge and which they are inclined not to notice. They are illustrated in Figure 2:

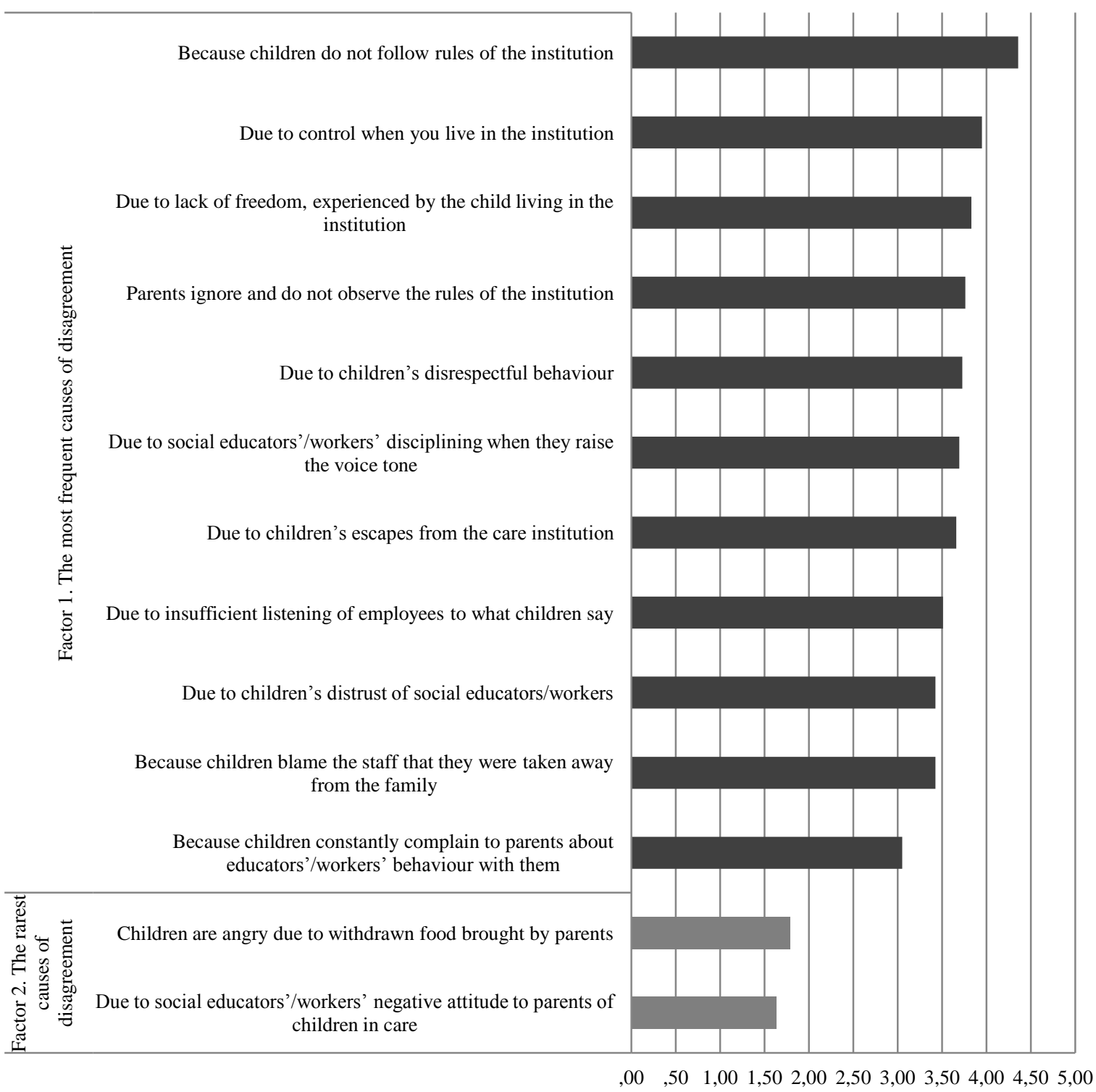

Fig. 2. Causes of Disagreements between Specialists and Learners

Specialists' and learners' research data disclose that presented statements semantically distributed into two factors. The means of responses to statements of the first factor, the most common causes of child-specialist disagreements 
Daiva Alifanoviene, Asta Vaitkeviciene, Dovile Kauneckiene, Rita Orska. Development of Communication Possibilities Between Participants of the Temporary Child Guardianship...

reveal (see Fig. 2) that respondents strongly agreed that the most common conflicts between the staff and children in care stemmed from non-observance of rules of the institution $(\mathrm{M}=4,36, \mathrm{SD}=1,39)$, partially agreed that there were disagreements due to control of living in the institution, experienced by the child $(\mathrm{M}=3,85, \mathrm{SD}=1,30)$, the lack of freedom $(\mathrm{M}=3,83, \mathrm{SD}=1,24)$, children's disrespectful behaviour with the staff $(\mathrm{M}=3,73, \mathrm{SD}=1,20)$, disciplining when the staff raise the tone of voice $(\mathrm{M}=3,69, \mathrm{SD}=1,26)$, children's escapes from the institution $(\mathrm{M}=3,66, \mathrm{SD}=1,29)$, lack of listening of the staff to what the child says $(\mathrm{M}=3,51, \mathrm{SD}=1,19)$. Specialists who took part in the research also partially agree that children do not trust social educators / social workers $(\mathrm{M}=3,42$, $\mathrm{SD}=1,19)$ and blame the staff for taking them away from the family $(\mathrm{M}=3,42$, $\mathrm{SD}=1,31)$. Respondents doubt whether disagreements between them and children arise due to children's complaints to parents about behaviour of the staff with them $(\mathrm{M}=3,05, \mathrm{SD}=1,31)$. These data disclose that children often find it difficult to accept that they cannot live in their own family. Due to such defiance with the existing situation children do not observe the rules of the institution, accuse the staff of separation from parents, display disrespectful behaviour directed towards the staff, resolve to escape from the care institution, all of it resulting in conflict situations. Meanwhile, the lack of listening of the staff to learners can promote learners' hostility, negative attitude towards the staff. This results in tense and unkind child-staff relationships.

The means of evaluations of the second factor statements, the rarest causes of child-staff conflicts, show that respondents do not agree with the statements about causes of conflicts: children are angry due to withdrawal of food brought by parents $(\mathrm{M}=1,78, \mathrm{SD}=1,23)$ and due to social educators' / social worker' negative attitude towards parents of children in care $(\mathrm{M}=1,63, \mathrm{SD}=1,31)$. These data suggest that professionals do not have prejudices directed against biological parents and learners, they often do not even know why the child in the institution is angry, annoyed, which indicates absence of a close relations between the staff and children.

Data analysis showed that estimators of causes of conflicts between parents who have temporarily lost the right to the child's care and the staff fluctuated from 1,68 to 4,41. In most cases, respondents chose the answer "partly agree" for statements: parents do not fulfil agreements $(\mathrm{M}=4,41, \mathrm{SD}=1,40)$, parents themselves spark conflicts $(\mathrm{M}=3,86, \mathrm{SD}=1,30)$, parents are angry on social educators / social workers due to taken away children $(\mathrm{M}=3,78, \mathrm{SD}=1,37)$, parents ignore and do not comply with the rules of the institution $(\mathrm{M}=3,76$, $\mathrm{SD}=1,25)$, parents' negative approach to social educators / social workers working in the institution $(\mathrm{M}=3,71, \mathrm{SD}=1,25)$. It can also be noticed that evaluating these statements, respondents' opinion was more heterogeneous (SD ranges from 1,25 to 1,40 ). These research data enable to presume that parents of 
children who temporarily live in care institutions come to the institution with preconceived negative attitudes to working specialists, blame them for taking away their children and for this reason, they often do not fulfil agreements and do not observe the rules of the institution. This leads to children's longer stay in care institutions than it is sometimes planned.

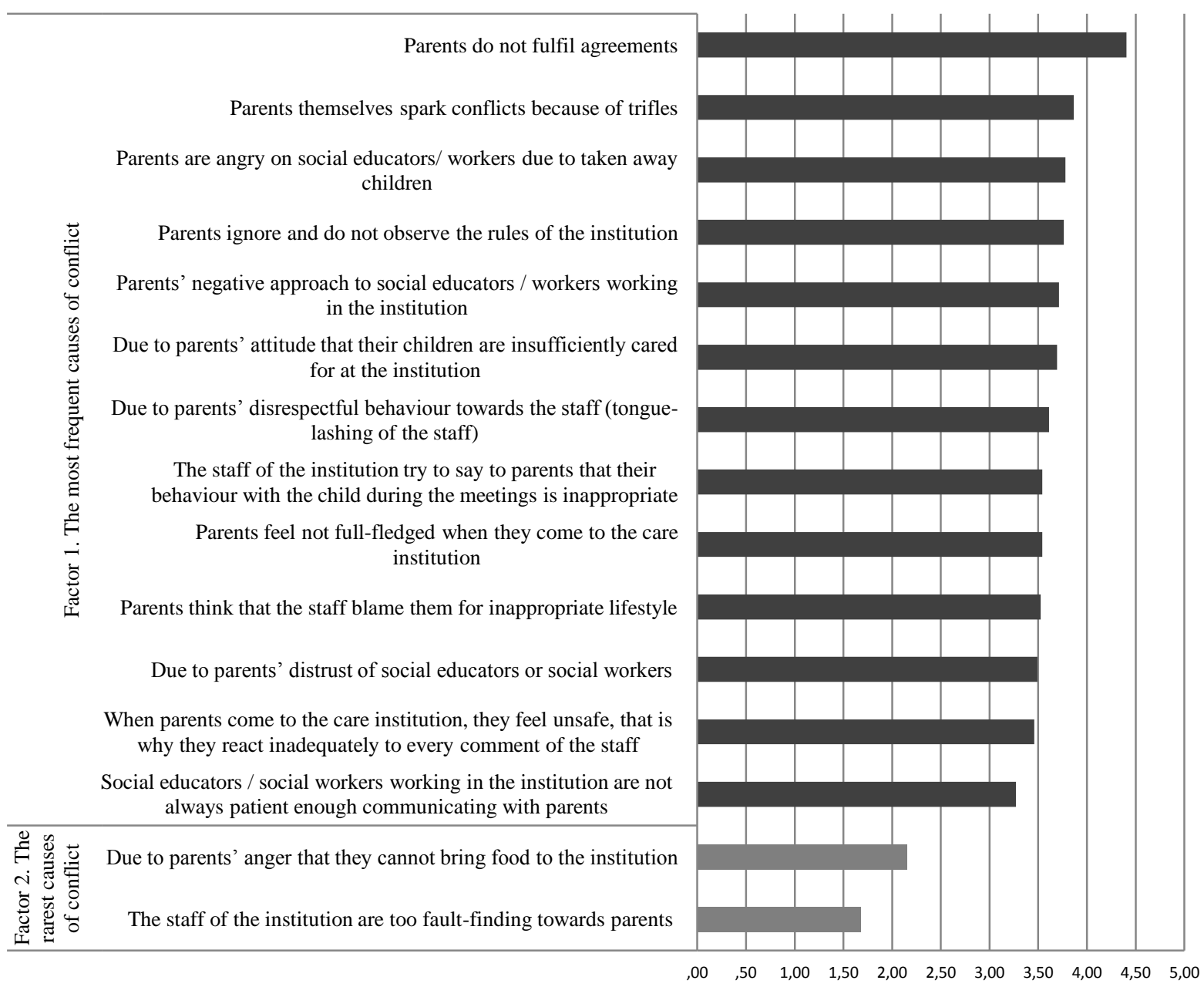

Fig. 3 Causes of Disagreements between Specialists and Biological Parents

In the course of the research we sought to find out how social educators / social workers contributed to the development of child-parent communication. The results of the factor analysis are presented in Figure 4: 
Daiva Alifanoviene, Asta Vaitkeviciene, Dovile Kauneckiene, Rita Orska. Development of Communication Possibilities Between Participants of the Temporary Child Guardianship...

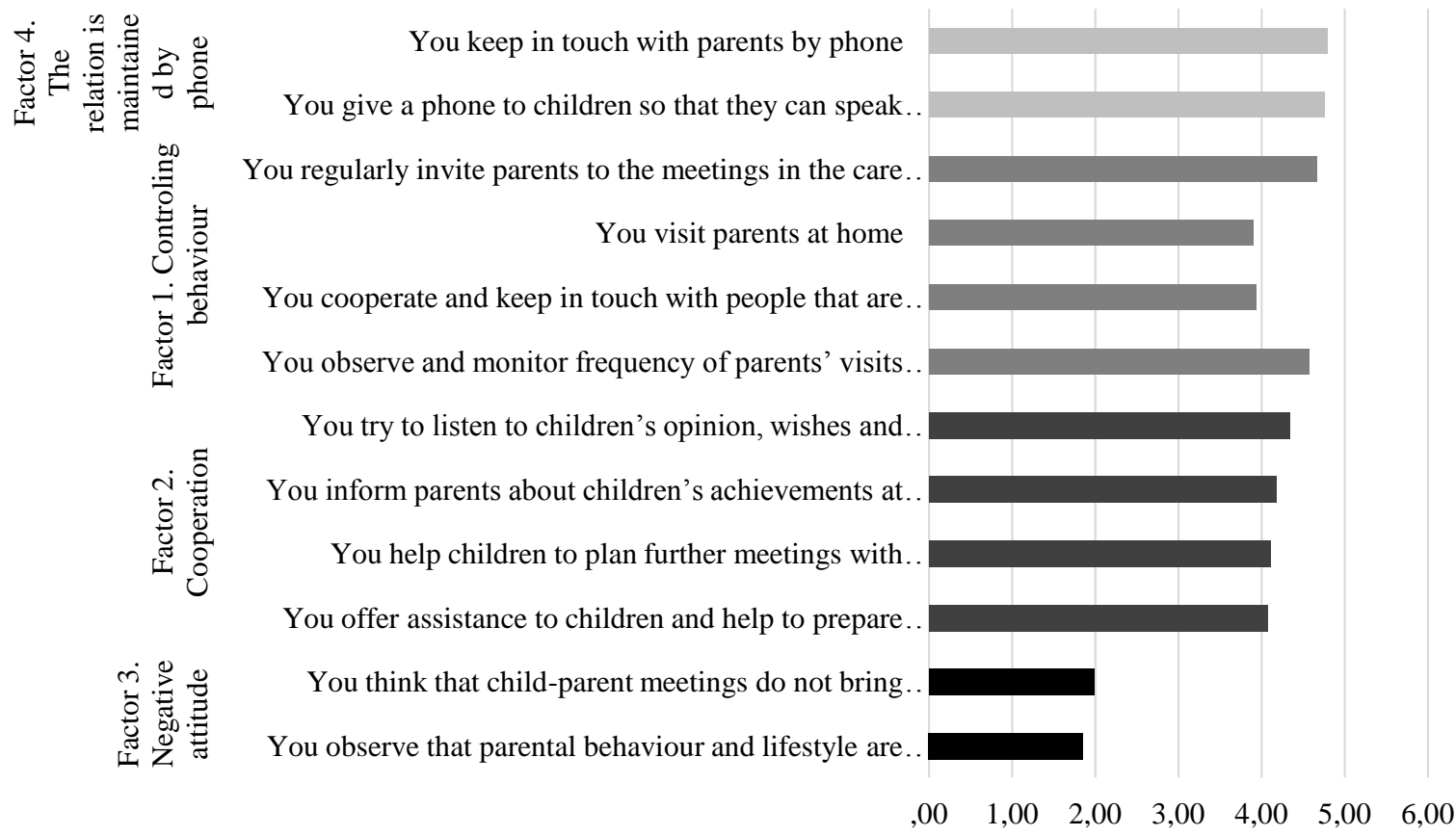

Fig. 4 Possibilities of Developing Communication between Participants of the Temporary Child Care Situation

The mean values evaluating statements of the first factor, controlling behaviour, show that the respondents completely agree that their assistance developing child-parent communication most often manifests itself in two ways: the staff regularly invite parents to the care institution $(\mathrm{M}=4,66, \mathrm{SD}=0,68)$ and observe and monitor frequency of parents' visits to their children $(\mathrm{M}=4,58$, $\mathrm{SD}=1,00)$. Research participants partially agree that in order to develop communication between learners and their parents, they cooperate and keep in touch with people that are close to the child and his / her parents $(\mathrm{M}=3,93$, $\mathrm{SD}=0,69)$ and visit parents at home $(\mathrm{M}=3,90, \mathrm{SD}=0,78)$. The obtained data reveal that social educators / social workers monitor visits to children, actively observe whether parents' lives are changing and how they are changing. In order to obtain sufficient information about the life of the family with which social educators / social workers work, they keep in touch with people from parents' environment. It can be assumed that this control is necessary seeking to achieve positive changes in parents' life and more frequent visits to their children. However, research results disclosed that specialists working in temporary care institutions little cooperate with other institutions and colleagues in order to share the good practice of developing communication between parents and children.

The means evaluating statements of the second factor, cooperation, show that the staff is trying to listen to children's opinion ( $\mathrm{M}=4,38, \mathrm{SD}=0,95)$, invites parents to the care institution on festive occasions $(\mathrm{M}=4,27, \mathrm{SD}=0,52)$ and 
informs parents about children's achievements at school, in after-school activities $(\mathrm{M}=4,17, \mathrm{SD}=0,67)$. These data suggest that in order to intensify communication between children and their biological parents and increase its quality, it is important that specialists should cooperate both with children and their biological parents. Listening to children, provision of information on children's progress to parents and efforts to invite parents to the festivals of the institution show that children and their parents are important and significant for specialists. It can be assumed that such strategy of specialists' communication with parents who have lost the right to the child's care would be effective and acceptable to parents, if they had serious reasons to change. On the other hand, it would be emotionally extremely difficult for the specialists to maintain such strategy for a long time, observing fruitlessness of their efforts.

The means evaluating the third factor statements, negative attitude, show that social educators / social workers working in temporary care institutions are willing to help, cooperate with biological parents. This statement is proved by respondents' strong disagreement on the following statements: believe that child-parent meetings do not bring anything good $(\mathrm{M}=1,98, \mathrm{SD}=0,95)$ and observe that parental behaviour is not improving and see no sense to help them $(\mathrm{M}=1,85, \mathrm{SD}=1,08)$. These data suggest that social educators / social workers working in care institutions are benevolent-minded with regard to biological parents of children in care and often seek to develop their mutual communication.

The means of evaluations of the fourth factor statements, promotion of communication by phone, show that the respondents completely agree with statements that the very staff keep in touch with parents, communicate by phone $(\mathrm{M}=4,80, \mathrm{SD}=0,44)$ and give the phone to children so that they can communicate with parents $(\mathrm{M}=4,76, \mathrm{SD}=0,46)$. These data enable to assume that both children and specialists working in care institutions often communicate with parents by the most accessible technological means, the telephone. It is evident that modern technologies facilitate the possibility of contacting parents and at least keeping in touch with them but it is likely that the personal contact and direct meeting would be more efficient.

\section{Conclusions}

1. Children living in the temporary care situation go through a painful separation from their parents. This indicates the importance of communication, relation with parents for the child, which is possible only promoting constant, continuous communication between children and their biological parents. Social educators / social workers working in temporary care institutions and namely these specialists who should promote parents 
Daiva Alifanoviene, Asta Vaitkeviciene, Dovile Kauneckiene, Rita Orska. Development of Communication Possibilities Between Participants of the Temporary Child Guardianship...

to visit their children and perform the roles of the mediator, promoter, developing communication between children and their biological parents.

2. The research data disclosed that social educators / social workers working in temporary care institutions observe conflicts between children in care and their parents, disclose causes of conflicts between them and parents who have lost the right to the child's care. In social educators' and social workers' opinion, the main causes of conflicts between children in care and their parents are: parents' unfulfilled promises, parental alcoholism and parent's rare visits. These causes stem from parents' inappropriate lifestyle, which actually is the cause of their children's care restriction. It is evident that conflicting with their parents, children cannot accept their behaviour and object. The most common conflicts between the staff and children in care are caused by non-observance of the rules of the institution; children's experienced control, living in the institution; the lack of freedom; the children's disrespectful behaviour with the staff; disciplining of the staff when they raise the voice tone; children's escapes from the institution; inadequate listening of the staff to what the child says. Most often conflicts between social educators, social workers and parents who have lost the right to the child's care arouse due to parents' unfulfilled agreements; parents' anger on social educators / social workers for taken away children; parents' disregard and non-observance of the rules of the institution; parents' negative attitude towards social educators / social workers working in the institution.

3. The research data analysis shows that the participants of the temporary child care have considerable communication development resources. Specialists tend to goodwillingly keep in touch, mediate between learners and biological parents, inviting them to come to care institutions for talks, to attend festivals, visiting them at home and watching the changing social situation so that in the event of positive changes children have a possibility to return to their biological families. The factor analysis disclosed a 4-way structure of developing communication between specialists and parents who have temporarily lost their right to child care. Social educators / social workers of children's care homes most effectively use the controlling communication strategy (Factor 1), although it is quite sensitively perceived and accepted by parents who have lost their right to child care. Slightly less significant is the cooperation strategy (Factor 2), although it would be most acceptable for parents with a strong motivation to change and would least violate their dignity. Means and standard deviation witness that social educators / social workers of children's care homes do not use the negative attitude communication strategy (Factor 3). It may be that this strategy emerged due to reluctance of the staff of children's care homes to 
openly disclose peculiarities of their work. According to the means of estimators of social educators / social workers of children's care homes, the telephone communication strategy (Factor 4) remains the most popular but using solely this strategy, important actual details in the behaviour of parents who have lost the right to the child's care and in their living environment would be missed.

4. Research results disclosed that specialists working in temporary care institutions little cooperated with other institutions and colleagues in order to better share the good practice of developing communication between children and parents, poorly promoted parents to solve problems, poorly encouraged children to speak in order to find out problems of communication with parents, did not try to talk with parents after meetings with children, did not listen to their complaints. It can be assumed that the development of the cooperation strategy of social educators / social workers of child care institutions combined with the controlling communication strategy would be those trends of specialists' activities which would promote development of communication between children who are temporarily deprived of parental care and their biological parents, enable parents to change their way of life and accelerate children's return to their native families.

\section{References}

Alifanovienė, D., Vaitkevičienė, A., \& Kauneckienė, D. (2015). Laikinosios vaikų globos situacijos dalyvių bendravimo ypatumų analizè. [Analysis of Communication Peculiarities of Participants of the Temporary Child Guardianship Situation]. Specialusis ugdymas, 1 (32), 229-244.

Butvilas, T. (2004). Šeimoje netekti patyrusiu vaiku (7-11 metu) socializacija ir pedagogines pagalbos strategijos. [Children (age 7-11) who have experienced loss in the family socialization and educational assistance strategies]. Daktaro disertacija, Šiauliu universitetas.

Convention on the Rights of the Child. 1989. (UN). Ratified in Lithuania 1995. (LRS) (LT).

Dèl Jungtiniu Tautu vaiko teisiu konvencijos igyvendinimo ataskaitos patvirtinimo. [Approval of United Nations child's rights convention implementation report]. 2004 (LRV) (LT).

Dèl vaiko gerovès valstybès politikos koncepcijos patvirtinimo. [Approval of child's welfare policy concept]. 2003. (LRS) (LT).

Dèl vaiko gerovès 2013-2018 m. programos patvirtinimo. [Approval of the 2013-2018 child's welfare programme]. 2012. (LR SADM) (LT).

Kauneckiene,, D. (2014). Vaiku, kuriems skirta laikinoji globa, bendravimo su biologiniais tevais pletojimas. [Children, which is intended for temporary custody to biological parents for the development of communication]. Magistro darbas, Šiaulių universitetas.

Kondrotaite, G. (2006). Socialinès rizikos šeimos Lietuvoje: atvejo studija. [Social risk families in lithuania: case study]. Filosofija. Sociologija. 4, 55-60. 
Daiva Alifanoviene, Asta Vaitkeviciene, Dovile Kauneckiene, Rita Orska. Development of Communication Possibilities Between Participants of the Temporary Child Guardianship...

Lietuvos Respublikos civilinis kodeksas. [The Civil Code of the Republic of Lithuania] 2000. (LRS) (LT).

Lietuvos Respublikos vaiko teisiu apsaugos pagrindu istatymas. [Lithuania Rights of the Child Law of Protection]. 1996. (LRS) (LT).

Pakalniškienè, V. (2012). Tyrimo ir juertinimo priemoniu patikimumo ir validumo nustatymas. [Validity and credibility assessment of research and evaluation tools]. Vilnius: Vilniaus universiteto leidykla.

Pileckaitė-Markovienè, M., \& Lazdauskas, T. (2007). Šeima ir tèvu globos netekusio vaiko raida. [Family the development of children who've lost parental care]. Vilnius: Vaga.

Radzevičienè, L. (1999). Socialinio pedagogo vaidmuo vaiku globos ir ugdymo istaigose. [The role of social pedagogues in childcare and educational institutions]. J. Ambrukaitis (Ats. red). Šiuolaikinès ir specialiosios pedagogikos problemos. Mokslo konferencijos medžiaga (p. 38-40). Šiauliai: Šiaulių universiteto leidykla.

Rimkevičienè, V. (2007). Socialiniu pedagogu veiklos specifika vaiku globos namuose. [Particularity of the activity of social pedagogues in foster home for children]. Magistro darbas, Šiaulių universitetas.

Samašonok, K., Žukauskienè, R., \& Gudonis, V. (2006). Paaugliu, gyvenančiu globos institucijose ir pilnose šeimose, kognityviniu strategiju ir elgesio bei emociniu problemu ypatumai. [Features of cognitive strategies and emotional problems of orphaned and abandoned teenagers who live in institutions, and teenagers who live with a parent (parents)]. Mokslo darbai. Socialinis darbas, 5 (2), 45-54.

Sivec, L. (2005). Vaiku globos instituciju auklètojo pedagoginès funkcijos. [Pedagogical functions of educators in childcare institutions] Magistro darbas, Vilniaus pedagoginis universitetas.

Vitkauskas, K. (2010). Vaiko globos organizavimo principu igyvendinimas Lietuvoje. [Implementation of Principles for Child Guardianship Organization in Lithuania]. Viešoji politika ir administravimas, 31, 136-146. 